\title{
Performance Evaluation on Science and Innovation Management Process in A Cuban Medical University
}

\section{Guillermo RC* and Arialys HN}

Professor, Medical University Sciences, Cuba

*Corresponding author: Guillermo Ramos Castro, Professor at the University of Medical Sciences, Central Highway, Km, km 101, Matanzas, Cuba, Email: gramos.mtz@infomed.sld.cu

\section{Research Article \\ Volume 3 Issue 6}

Received Date: November 11, 2020

Published Date: November 23, 2020

DOI: $10.23880 /$ jqhe-16000188

\section{Abstract}

Quality represents a form of management focused and concerned on user satisfaction, as well as processes and results improvement. In an institution like the university, quality must involve all academic and administrative activities. Many higher education institutions use generic quality management models as a way to improve the performance of their processes and to introduce control mechanisms for efficiency seeking. In this regard, universities have developed performance evaluation indicator systems based on academic's scientific productivity. The main reason behind evaluation through performance criteria is that these measures drive improvement on the quality of service delivery. A critical analysis shows that difficulties persist in facing quality assessment processes and discrete values are observed in the indicators from a quantitative point of view. The purpose of this study is to evaluate the performance of the Science and Innovation Management process at the University of Medical Sciences of Matanzas as a contribution to institutional accreditation achievement.

Methodology \& Theoretical Orientation: it was carried out a non-experimental, descriptive and quantitative cross-sectional research around performance evaluation. A diagnosis and subsequent analysis of Science and Technological Innovation processes based on relevant indicators was performed.

Findings: The budget spending for research activities is, in general, not satisfactory; only $14.3 \%$ of academic departments execute more than $50 \%$. However, there is an increase in evaluation costs, with values range from $28 \%$ to $36 \%$.

Conclusion \& Significance: The application of generic quality tool to evaluate the performance of the Science and Innovation process at the Medical University, proved to be relevant to boost quality and efficiency based improvement in academic processes.

Keywords: Health Sciences; Technology and Innovation Management; Quality Management; Academic Performance

\section{Introduction}

Quality represents a form of management focused and concerned on user satisfaction, as well as processes and results improvement. In an institution like the university, quality must involve all academic and administrative activities [1].
Many higher education institutions as a strategy use generic quality management models, based on the ISO 9001 standard and excellence awards as a way to improve the performance of their processes and to introduce control mechanisms for efficiency seeking [2]. 
The evaluation instruments proposed in these models are acknowledged to focus on improving management and results of health educational organizations. The satisfaction evaluation, quality costs and audits are notorious instruments of quality management systems; they lead these organizations into reviewing their processes, procedures and measures, and therefore provide redesign alternatives in accordance to new demands of the Higher Education agencies around performance improvement. based on academic's scientific productivity $[3,4]$.

The main reason behind evaluation through performance criteria is that these measures drive improvement on the quality of service delivery. A critical analysis shows persistent flaws in quality evaluation processes and from a quantitative point of view discrete values are observed in the quality indicators.

The purpose of this study is to evaluate the performance of the Science and Innovation Management process at the University of Medical Sciences of Matanzas as a contribution to institutional accreditation achievement.

\section{Methods}

It was carried out a non-experimental, descriptive and quantitative cross-sectional research around performance evaluation. A diagnosis and subsequent analysis of Science and Technological Innovation processes based on relevant indicators was performed; it consisted of: The development of academic audits according to the methodology described in ISO 19011.2018. Evaluation of quality costs. Application of customer satisfaction surveys related to scientific activities. The study was supported by statistical analysis, based on SPSS program.

\section{Results}

The results from table 1 show that only in less than half of analyzed departments more than $80 \%$ of the professors are linked to research projects. The Budget spending is in general not satisfactory; only $14.3 \%$ execute more than $50 \%$. The rest report execution values below $50 \%$. Regarding the publication index, $57.1 \%$ do not publish or concentrate the publications in a very small group of teachers, so it does not satisfy the quality standard.

\begin{tabular}{|c|c|c|c|c|c|}
\hline Variable & Frequency & Percent & Variable & Frequency & Percent \\
\hline \multicolumn{3}{|c|}{ Professors linked to Research Projects } & \multicolumn{3}{|c|}{ Budget expending } \\
\hline None & 1 & 14.3 & Ninguno & 2 & 28.6 \\
\hline Less than $50 \%$ & 1 & 14.3 & Up to $25 \%$ & 2 & 28.6 \\
\hline $50 \%$ to $59 \%$ & 1 & 14.3 & between $26 \%-49 \%$ & 2 & 28.6 \\
\hline $60 \%$ to $79 \%$ & 1 & 42.9 & between $76 \%-100 \%$ & 1 & 14.3 \\
\hline $80 \%$ or more & 3 & 42.9 & & & \\
\hline Total & 7 & 100 & Total & 7 & 100 \\
\hline \multicolumn{3}{|c|}{ Index of publications per professor } & \multicolumn{3}{|c|}{ Publications in not own journals } \\
\hline Not publishing & 4 & 57.1 & Less than $25 \%$ & 2 & 28.6 \\
\hline 1 Publication & 2 & 28.6 & between $26 \%$ - $50 \%$ & 3 & 42.9 \\
\hline 3 o more publications & 1 & 14.3 & None & 2 & 28.6 \\
\hline Total & 7 & 100 & Total & 7 & 100 \\
\hline
\end{tabular}

Source: self-made.

Table 1: Projects, publications and Budget spending.

The results in table 2 show an increase in evaluation costs. Its result is associated with the increase in inspections and audits (academic and quality), as well as the application of surveys that allow the evaluation of the level of satisfaction perceived by professors, which is focused on the performance of science management process. According to Harrington they should be $35 \%$, for Garbey, $10-50 \%$ and Juran, $40 \%$ [5]. The results of the research offer increasing values of $28 \%$ up to $36 \%$ during $2019-2020$ periods. 


\begin{tabular}{|c|c|c|c|}
\hline Quality Costs & Dec. 2019 & Jan. 2020 & Feb. 2020 \\
\hline Prevention Costs & 5130.67 & 2936.84 & 2856.22 \\
\hline Evaluation Costs & 3364.44 & 1851.6 & 2741.18 \\
\hline Internal Failure Costs & 2666.67 & 907.43 & 1856.09 \\
\hline External Failure Costs & 850 & 200 & 250 \\
\hline Total Cost of Quality & 12011.78 & 5895.88 & 7703.49 \\
\hline Cost of Prevention / Total Cost of Quality & 0.427 & 0.498 & 0.37 \\
\hline Evaluation Cost / Total Quality Cost & 0.28 & 0.314 & 0.36 \\
\hline Cost of Failures / Total Cost of Quality & 0.293 & 0.188 & 0.27 \\
\hline
\end{tabular}

Source: self-made.

Table 2: Quality Costs.

The results in table 3 showed a higher percentage in the satisfaction levels of the professionals in the performance of the science management process. However, some of the indicators associated with the Budget expending reflect persistence of fails affecting the development of research projects.

\begin{tabular}{|c|c|c|c|}
\hline ITEM & Valid & Frequency & Percent \\
\hline \multirow{4}{*}{$\begin{array}{l}\text { Quality and relevance of the recommendations and suggestions of } \\
\text { experts and specialists }\end{array}$} & Deficient & 2 & 6.7 \\
\hline & Regular & 4 & 13.3 \\
\hline & Adequate & 24 & 80 \\
\hline & Total & 30 & 100 \\
\hline \multirow{5}{*}{ How important is the project budget? } & 0 & 1 & 3.3 \\
\hline & None & 1 & 3.3 \\
\hline & Some & 4 & 13.3 \\
\hline & Much & 24 & 80 \\
\hline & Total & 30 & 100 \\
\hline \multirow{5}{*}{$\begin{array}{l}\text { What level of knowledge have you received to plan your research } \\
\text { activities? }\end{array}$} & 0 & 4 & 13.3 \\
\hline & None & 4 & 13.3 \\
\hline & Some & 12 & 40 \\
\hline & Much & 10 & 33.3 \\
\hline & Total & 30 & 100 \\
\hline \multirow{5}{*}{$\begin{array}{l}\text { Have you used the planned budget for the development of your } \\
\text { scientific activities and results? }\end{array}$} & 0 & 5 & 16.7 \\
\hline & None & 5 & 16.7 \\
\hline & Some & 14 & 46.7 \\
\hline & Much & 6 & 20 \\
\hline & Total & 30 & 100 \\
\hline
\end{tabular}

Source: self-made.

Table 3: The client's satisfaction.

\section{Discussion}

The literature review revealed the need to incorporate principles, models and indicators that are related to the expectations, strategic projections and potential of the institutions [6].

Although the most frequent criterion to measure the performance of universities is teaching and learning; research, seen as the capacity of universities to generate new 
knowledge, constitutes a basic indicator to evaluate their performance through rankings that classify universities based on their scientific production [7].

Indicators reflected in table 1 such as: research projects, publications by professor, publications in other journals and professors with a doctorate in science are of utmost importance to evaluate the performance of an educational organization.

Efficiency represents one of the performance indicators and is described within the eight measures to evaluate the performance of processes [8]. The budget executed in scientific-research activities, the percentage of professors linked to research projects, the publication rate per professor are some of the efficiency indicators selected to evaluate the performance of the research process.

\section{Conclusions}

The application of generic quality tools to evaluate the performance of the Science and Innovation process at the Medical University, proved to be relevant to boost quality and efficiency based improvement in academic processes.

The data provided by the research allowed evaluating the behavior of the performance indicators of the Science and Innovation process at the Medical University.

The study revealed the opportunity and scientific value of approaching the evaluation of the scientific-research performance of the medical university, based on tools such as quality, academic and quality cost audits.

\section{References}

1. Elazeem Osman ME (2019) Impact of Implementing
ISO 9001: 2015(2019) Quality Management Systems on Employee's Satisfaction Case study: Central Trading Company (CTC group) [MSc. in Total Quality Management and Excellence]. Sudan: University for Science and Technology pp: 72.

2. Africano N, Rodrigues AS, Santos G (2019) The Main Benefits of the Implementation of the Quality Management System in Higher Education Institutions in Angola. Quality Innovation Prosperity 23(3): 122-135.

3. Abbeh O Donatus Ngige C, Azuka OM (2019) Total quality management and organizational performance: An exploration of issues Advance Journal of Management, Accounting and Finance 4(6): 21.

4. Peters MA (2017) Global university rankings: Metrics, performance, governance. Educational philosophy and theory 51(1): 5-13.

5. Berni Moran LR, Zambrano Camacho NR, Chávez Garcés AM (2018) Procedimiento para determinar los costos de calidad por fallas en procesos empresariales Revista ESPACIOS 39(42): 28.

6. Murillo Mora M (2019) Gestión universitaria. Concepto y principales tendencias. Cuadernos de Educación y Desarrollo pp: 1-14.

7. Machorro F, Romero MV (2017) Proposal for a SelfAssessment Instrument of Organizational Performance in Public Institutions of Higher Education in Mexico 10(3): 1-8.

8. Chase RB, Jacobs FR, Aquilano NJ (2019) Diseño del producto y selección del proceso. Administración de la producción y operaciones. 10 edición ed. México, pp: 112.

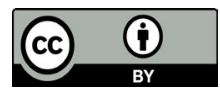

